\title{
IDENTITY OF DNA FROM ESCHERICHIA COLI AND FROM ITS RESPIRATORY-DEFICIENT MUTANT, AND THE PHYSIOLOGICAL SIMILARITY OF THE LATTER WITH LACTOBACILLI
}

\author{
KENJI SAKAGUCHI, EIICHI NAKANO, ${ }^{*}$ HIROSHI SEKINE,* AND \\ HIDEO TAKAHASHI** \\ Mitsubishi-Kasei Institute of Life Sciences, Machida-shi, Tokyo \\ *Noda Institute for Scientific Research, Noda-shi, Chiba-ken \\ **The Institute of Applied Microbiology, University of Tokyo, Hongo, Tokyo
}

(Received October 24, 1973)

\begin{abstract}
The respiratory-deficient mutant $\mathrm{H}_{7}$, obtained by Beljanski from Monod's strain of Escherichia coli, differs in several respects from the parent strain. Comparison of the DNAs from the two cultures has revealed complete homology. Physiologically, the mutant resembles the homofermentative lactobacilli; it does not contain catalase or cytochromes, grows better in the absence than in the presence of air, produces lactic acid from glucose even under aerobic conditions, and requires amino acids for growth. These properties are discussed in relation to the respiratory deficiency, as is their bearing on the evolutionary status of the lactobacilli.
\end{abstract}

$\operatorname{BELJANSKI}(1,2)$ has reported a streptomycin-resistant, hemin-requiring mutant, $\mathrm{H}_{7}$, obtained from Monod's strain of Escherichia coli by serial transfer on hemin-containing media with increasing concentrations of streptomycin (4 to $100 \mu \mathrm{g} / \mathrm{ml}$ ). The mutant grows more slowly than the parent strain, does not oxidize glucose or number of other substrates, is catalase negative, and does not show absorption bands characteristic of cytochromes. The latter, as well as catalase activity, appears, however, if the mutant is cultivated in hemin-containing media. The mutant strain is resistant to six of the seven $E$. coli bacteriophages, $\mathrm{T}_{1}-\mathrm{T}_{7}$, the sole exception being $\mathrm{T}_{6}$. The sensitivity to $\mathrm{T}_{6}$ is one of the few characteristics the mutant shares with the parent strain; in several other respects it resembles the homofermentative lactobacilli. It therefore seemed important to compare the DNAs of the parent and mutant strains, and to conduct some additional physiological studies. 


\section{MATERIALS AND METHODS}

Microorganisms. The parent and $\mathrm{H}_{7}$ mutant strains were generously supplied by Dr. M. Beljanski of the Pasteur Institute.

Culture Methods. The culture medium generally used contained; beef extract (Wako Pure Chemicals Co.), $0.3 \%$; peptone (Wako Pure Chemicals Co.), $1 \%$; glucose, $0.2 \% ; \mathrm{NaCl}, 0.5 \%$; its $\mathrm{pH}$ was 7.0 .

For determining nutritional requirements and fermentation products from glucose, Vogel and Bonner's basal medium $\left(\mathrm{MgSO}_{4} \cdot 7 \mathrm{H}_{2} \mathrm{O}, 0.02 \%\right.$; citric acid monohydrate, $0.2 \% ; \mathrm{K}_{2} \mathrm{HPO}_{4}, 1 \%$; $\mathrm{NaNH}_{4} \mathrm{HPO}_{4} \cdot 4 \mathrm{H}_{2} \mathrm{O}, 0.25 \%$, in $\mathrm{H}_{2} \mathrm{O}$, prepared from a 50-fold concentrated stock) was used; amino acids were added to the diluted medium, which was then autoclaved for $10 \mathrm{~min}$ at $120^{\circ}$. Separately autoclaved glucose solution $(16 \%)$ was added to a final concentration of $0.16 \%$. Hemin was supplied in the form of a solution of $6 \mathrm{mg}$ hemin (Nutritional Biochem. Corp.) in $8 \mathrm{ml}$ of $70 \%$ ethanol and one drop of $0.6 \mathrm{~N} \mathrm{NH} \mathrm{NH}_{4} \mathrm{OH}$ to a final concentration of $6 \mu \mathrm{g} / \mathrm{ml}$.

The $\mathrm{H}_{7}$ strain was usually grown anaerobically in a vacuum jar at $30^{\circ}$.

Isolation and hybridization of DNA. The cells were disrupted according to MARMUR's method (3). DNA was extracted with buffered phenol at $\mathrm{pH} 9$ and purified as described by SAITO and MiURA (4). $\mathrm{T}_{\mathrm{m}}$ values were determined by the method of MARMUR et al. $(5,6)$. Hybridization of DNA preparations in agar was measured by MCCARTHY and BoLTON's method (7), as modified by TAKAHASHI et al., $(8,9)$.

${ }^{32} \mathrm{P}$-labeled DNA was collected from a methylated albumin-kieselguhr column (7), dialyzed against standard saline citrate (SSC) solution, and sheared by exposure to ultrasonic treatment $(10 \mathrm{Kc} / \mathrm{sec})$ for $10 \mathrm{~min}$; this usually yields fragments with an average molecular weight of $6 \times 10^{5}$. The sheared DNA was denatured $\left(10 \mathrm{~min}\right.$ at $\left.100^{\circ}\right)$, and a solution containing $0.1-0.2 \mu \mathrm{g}$ DNA $\left(c a .10^{4} \mathrm{cpm} /\right.$ $\mu \mathrm{g}$ ) mixed with $400 \mathrm{mg}$ of an agar gel containing $20 \mu \mathrm{g}$ of denatured, long ${ }^{12} \mathrm{C}-\mathrm{DNA}$. After $12 \mathrm{hr}$ at $60^{\circ}$ the mixture was cooled slowly, washed with $150 \mathrm{ml}$ of doubly concentrated SSC, the bound ${ }^{32} \mathrm{P}-\mathrm{DNA}$ eluted with $10 \mathrm{ml}$ of $0.01 \times \mathrm{SSC}$, and the bound radioactivity was counted. This procedure showed sufficient accuracy in order to give the homology index between DNAs obtained from various bacilli, $100-15 \%$. The hybridization between Bacillus subtilis DNA and E. coli DNA was less than $5 \%(10)$.

Analysis of organic acids in fermented media. Cultures in the synthetic medium, supplemented with $20 \mathrm{~g}$ glucose, $500 \mathrm{mg}$ L-glutamic acid, $400 \mathrm{mg}$ DL-aspartic acid, $100 \mathrm{mg}$ L-cystine, $200 \mathrm{mg}$ DL-threonine, $100 \mathrm{mg}$ L-lysine, $200 \mathrm{mg}$ DL-methionine, $200 \mathrm{mg}$ DL-isoleucine, and $100 \mathrm{mg}$ L-leucine per liter, were incubated aerobically and anaerobically for 6 days. After acidification the organic acids were extracted with ether, fractionated by silica gel chromatography according to BULEN et al. (11), and titrated with $0.01 \mathrm{~N} \mathrm{NaOH}$. 
Assay of bacterial growth. Growth was registered automatically with the biophotometric apparatus manufactured by Bonnet, Maury, Jouan \& Co. The medium used was 4-fold diluted Difco's antibiotic medium No. 3. Aerobic cultures were incubated with shaking; for anaerobic cultures the medium, after autoclaving, rapid cooling and inoculation, was covered with a $1-\mathrm{cm}$ thick layer of sterilized paraffin oil.

\section{RESULTS}

\section{Comparison of DNA from the parent and mutant strains}

The respiratory-deficient mutant differs in so many respects from Monod's original strain that it seemed important to establish the close similarity of their genomes. Efforts to obtain a back mutant of $\mathrm{H}_{7}$ by selection on minimal media or under aerobic conditions were fruitless. This may be explained by the fact that strain $\mathrm{H}_{7}$ had been obtained by a multi-step isolation on media with increasing streptomycin concentrations.

Comparison of DNA preparations from the parent and mutant strains revealed that the $\mathrm{T}_{\mathrm{m}}$ values (in SSC) were 90.9 and $91.2^{\circ}$, respectively, from which a GC content of 52.7 and $53.4 \%$ may be calculated. Thus, within the limits of experimental accuracy, identity seemed evident.

Hybridization experiments also showed close analogy between the DNAs of the two strains; this is shown by the data in Table 1 .

\section{Anaerobic character of the $H_{7}$ mutant}

The growth curves presented in Fig. 1 show that the parent strain grows much faster and more profusely than the $\mathrm{H}_{7}$ mutant, under both aerobic and anaerobic conditions, and that the mutant is inhibited by air. Addition of hemin to the

Table 1. Hybridization of DNA from Monod's strain of E. coli and from its $\mathrm{H}_{7}$ mutant.

\begin{tabular}{lcc}
\hline \multicolumn{3}{c}{${ }^{32} \mathrm{P} \mathrm{H}_{7}$ DNA input count $2324 \mathrm{cpm}$} \\
\hline Cold DNA in agar & $\begin{array}{c}\text { bound count } \\
(\mathrm{cpm})\end{array}$ & $\%$ bound \\
\hline Monod's strain DNA & 1452 & 62.8 \\
H7 DNA & 1406 & 60.5 \\
Calf thymus DNA & 21 & 0.9 \\
\hline \multicolumn{3}{c}{ 32P Monod's strain DNA input count $2852 \mathrm{cpm}$} \\
\hline Cold DNA in agar & bound count & $\%$ bound \\
\hline Monod's strain DNA & $(\mathrm{cpm})$ & \\
\hline H DNA & 1669 & 58.3 \\
Calf thymus DNA & 1685 & 59.2 \\
\hline
\end{tabular}




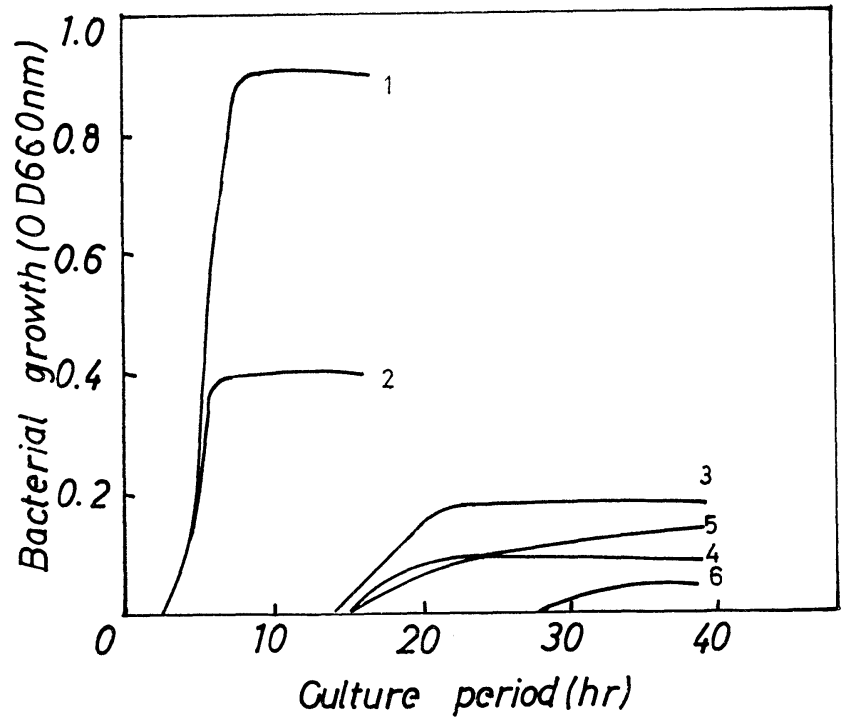

Fig. 1. Growth curves of the parent and mutant strains under aerobic and anaerobic conditions.

1, Parent strain, aerobic culture; 2, Parent strain, anaerobic culture; $3, \mathrm{H}_{7}$ strain, anaerobic culture, hemin added; $4, \mathrm{H}_{7}$ strain, anaerobic culture; $5, \mathrm{H}_{7}$ strain, aerobic culture, hemin added; $6, \mathrm{H}_{7}$ strain aerobic culture.

medium improves the development of the latter, but even under these conditions aerobic growth lags behind anaerobic growth.

\section{Nutritional requirements of the $H_{7}$ mutant}

Although Monod's original strain grew well in Vogel and Bonner's glucosemineral medium, the mutant failed to develop in it unless casamino acids (Difco, vitamin-free) or a mixture of amino acids was added. Vitamins were not required. Experiments with media from which a single amino acid had been omitted (12) showed that only cystine is essential. In additional tests it was found that some other amino acids are stimulatory. Table 2 presents the results of such an experiment. In hemin-supplemented media this effect is more pronounced in aerobic than in anaerobic cultures.

Fermentation products formed by the parent and $H_{7}$ strains from glucose

Under anaerobic conditions $E$. coli normally produces one mole each of lactic acid, $\mathrm{CO}_{2}$, and $\mathrm{H}_{2}$, and one-half mole of acetic acid and ethanol per mole of glucose fermented (13). Aerobically, the main products are acetic acid and $\mathrm{CO}_{2}$, sometimes accompanied by formic acid $(14,15)$. This was the case on this parent strain. The respiratory-deficient mutant behaves differently. Under anaerobic conditions it produces far more lactic acid than the parent strain but small amount 
Table 2. Amino acid requirement of $\mathrm{H}_{7}$ strain.

\begin{tabular}{|c|c|c|c|c|c|c|c|c|c|c|}
\hline & & & & & & & & Cell & th (OD & nm) \\
\hline & & & Supplen & nents & & & & 3 days & 4 days & 6 days \\
\hline None & & & & & & & & 0 & 0 & 0 \\
\hline Cys & & & & & & & & 0 & 0 & 0.135 \\
\hline Cys, & Glu & & & & & & & 0.01 & 0.14 & 0.14 \\
\hline Cys, & Glu, & Asp & & & & & & 0.02 & 0.09 & 0.15 \\
\hline Cys, & Glu, & Asp, & Met & & & & & 0.01 & 0.11 & 0.30 \\
\hline Cys, & Glu, & Asp, & Met, & Ileu & & & & 0.02 & 0.13 & 0.36 \\
\hline Cys, & Glu, & Asp, & Met, & Ileu, & Thr & & & 0.01 & 0.10 & 0.35 \\
\hline Cys, & Glu, & Asp, & Met, & Ileu, & Thr, & Val & & 0.02 & 0.10 & 0.25 \\
\hline Cys, & Glu, & Asp, & Met, & Ileu, & Thr, & Val, & Leu & 0.13 & 0.14 & 0.25 \\
\hline $\begin{array}{l}\text { Cys, } \\
\text { Tyr }\end{array}$ & Glu, & Asp, & Met, & Ileu, & Thr, & Val, & Leu, & 0.02 & 0.14 & 0.26 \\
\hline $\begin{array}{l}\text { Cys, } \\
\text { Tyr, }\end{array}$ & $\begin{array}{l}\text { Glu, } \\
\text { Trp }\end{array}$ & Asp, & Met, & Ileu, & Thr, & Val, & Leu, & 0.27 & 0.28 & 0.33 \\
\hline $\begin{array}{l}\text { Cys, } \\
\text { Tyr, } \\
\text { Ser, }\end{array}$ & $\begin{array}{l}\text { Glu, } \\
\text { Trp, } \\
\text { Phe }\end{array}$ & $\begin{array}{l}\text { Asp, } \\
\text { Gly, }\end{array}$ & $\begin{array}{l}\text { Met, } \\
\text { His, }\end{array}$ & $\begin{array}{l}\text { Ileu, } \\
\text { Lys, }\end{array}$ & $\begin{array}{l}\text { Thr, } \\
\text { Ala, }\end{array}$ & $\begin{array}{l}\text { Val, } \\
\text { Arg, }\end{array}$ & $\begin{array}{l}\text { Leu, } \\
\text { Pro, }\end{array}$ & 0.15 & 0.19 & 0.18 \\
\hline
\end{tabular}

Amino acids were supplemented to $10 \mu \mathrm{g} / \mathrm{ml}$ as L-form. Abbreviations: Cys, cystine; Glu, glutamic acid; Asp, aspartic acid; Met, methionine; Ileu, isoleucine; Thr, threonine; Val, valine; Leu, leucine; Tyr, tyrosine; Trp, tryptophan; Gly, glycine; His, histidine; Lys, lysine; Ala, alanine; Arg, arginine; Pro, proline; Ser, serine; Phe, phenylalanine.

Table 3. Amount of carbon in acidic products, as per cent of glucose carbon disappeared.

\begin{tabular}{|c|c|c|c|c|c|c|c|c|}
\hline \multirow{3}{*}{$\begin{array}{l}\text { Product } \\
\text { ic acid }\end{array}$} & \multicolumn{4}{|c|}{ Anaerobic } & \multicolumn{4}{|c|}{ Aerobic } \\
\hline & \multicolumn{2}{|c|}{$\begin{array}{l}\text { Parent strain } \\
\text { - hemin +hemin }\end{array}$} & \multicolumn{2}{|c|}{$\begin{array}{c}\text { Mutant } \\
\text { - hemin + hemin }\end{array}$} & \multicolumn{2}{|c|}{$\begin{array}{c}\text { Parent strain } \\
- \text { hemin }+ \text { hemin }\end{array}$} & \multicolumn{2}{|c|}{$\begin{array}{c}\text { Mutant } \\
\text { - hemin }+ \text { hemin }\end{array}$} \\
\hline & 34 & 32 & 67 & 59 & - & - & 68 & 65 \\
\hline Acetic acid & 12 & 13 & 5.5 & 8 & 62 & 36 & 1 & 5 \\
\hline Succinic acid & 11 & 10 & 9 & 14 & - & - & - & - \\
\hline Formic acid & - & - & 4 & - & - & - & - & - \\
\hline Pyruvic acid & - & - & - & - & 2 & trace & 1 & 3 \\
\hline
\end{tabular}

of acetic acid; and in the presence of air lactic acid is again the predominant product. These results are shown in Table 3. The mutant produced no $\mathrm{H}_{2}$ gas.

\section{DISCUSSION}

The hybridization experiments, showing a close homology of the DNAs from the parent and $\mathrm{H}_{7}$ strains, support the view that the latter is indeed a genuine mutant of the former, even though it exhibits so many physiological differences. These can best be explained as the result of a rather drastic change in the biochemical machinery of the parent strain, induced by the exposure to high concentrations of streptomycin. 
Beljanski stated that the $\mathrm{H}_{7}$ strain lacks catalase and cytochromes, and does not oxidize various carbon compounds that are readily metabolized by the parent strain. Cells of the mutant grown in the presence of hemin exhibit catalase activity, contain cytochromes, and can oxidize organic substrates, though both the cytochrome content and the respiratory rate are lower than those of the parent strain.

The absence of cytochromes in mutant cells readily accounts for the shift from the "mixed acid" fermentation characteristic of $E$. coli to a predominantly lactic acid fermentation. This is analogous to the change from a butyric to a lactic acid fermentation by Clostridium butyricum in the presence of $\mathrm{CO}$ or $\mathrm{HCN}$, which was first discovered by KUBOwITZ (16), and subsequently explained by LIPMAN (17) as the result of the inability of the poisoned cells to oxidize pyruvate. Consequently this compound must function as the sole hydrogen acceptor needed for the conversion of triose phosphate to phosphoglyceric acid. In the present case it is the absence of a cytochrome system, rather than its inactivation by $\mathrm{CO}$ or $\mathrm{HCN}$, that would thus be responsible for the observed shift.

The requirement of the $\mathrm{H}_{7}$ strain for certain amino acids can be accounted for along a similar line. In cells unable to produce acetyl-CoA from pyruvate, the tricarboxylic acid cycle cannot operate and provide the building blocks for the synthesis of certain amino acids, nor can cyst(e)ine, recently shown to be formed by $E$. coli and Salmonella typhimurium from serine and acetyl-CoA (18), be manufactured $(19,20)$. Minor changes of their stimulatory effect could be explained from the physiological nature of the requirements, not a genetical one.

Several investigators have reported that streptomycin-resistant or -dependent microorganisms grow better in the absence than in the presence of air, and this appears to be correlated with damage to the electron transport system and inhibition of the TCA cycle (21-25). WATANABE (26) has found that in multi-step streptomycin resistant mutants genetically altered loci occur, distinct from the $\mathrm{Sm}^{\mathrm{r}}$ locus of the well-known ribosome-altered single-step mutant. This should therefore be expected to hold in the case of the $\mathrm{H}_{7}$ strain. Unfortunately, the mechanism whereby the gradual acquisition of streptomycin resistance causes the development of a respiratory deficiency is not known.

It is difficult to imagine that a respiratory system in which molecular oxygen functions as the final electron acceptor would have evolved before the accumulation of $\mathrm{O}_{2}$ in the atmosphere through green plant photosynthesis (27-29). Even though some types of oxidative metabolism, such as those operating in the sulfatereducing or methane-producing bacteria, may have evolved before the appearance of a fully functional cytochrome system, it is none the less reasonable to consider an anaerobic metabolism, such as the lactic acid fermentation in which cytochromes do not play a role, as the more primitive.

This raises the question whether the lactic acid bacteria should be considered as precursors or as descendants of organisms with a more versatile metabolic 
machinery. While the present investigation has shown that E. coli, through the loss of its respiratory mechanism, may be transformed into an organism that physiologically resembles the lactic acid bacteria, it still suggests that the latter may have developed as "loss mutant", not directly from $E$. coli whose mutant still retains its gram stain negative nature, but from other more appropriate ancestors. The broad range of the GC content of lactic acid bacteria DNA (33-53\% according to Gasser and Sebald (30), and GasSer and MANDel (31)) seems to imply a polyphyletic origin of the group as defined by S. ORLA-JENSEN (32).

The authors express their thanks to Dr. M. Beljanski for kindly sending them his strains. They thank Professors Y. Ikeda and H. Saito, who kindly gave them valuable suggestions and the opportunity to conduct this collaborative research. They are very grateful to Dr. T. Ando for his permission to use temperature shifting spectrophotometer. Their thanks are also due to Dr. S. Sugama for his help in the use of automatic biophotometer. They are grateful to Prof. C. B. Van Niel for advice, particularly in connection with the preparation of this manuscript.

\section{REFERENCES}

1) M. Beljanski, C. R. Acad. Sci., 240, 374 (1955).

2) M. Beljanski, Ann. Inst. Pasteur, 92, 396 (1957).

3) J. Marmur, J. Mol. Biol., 3, 208 (1961).

4) H. Saito and K. Miura, Biochim. Biophys. Acta, 72, 619 (1963).

5) J. MARmur and P. Doty, J. Mol. Biol., 5, 109 (1962).

6) J. Marmur, S. Falkow, and M. Mandel, Ann. Rev. Microbiol., 17, 329 (1963).

7) B. J. MCCARThy and E. T. Bolton, J. Mol. Biol., 8, 184 (1964).

8) H. Takahashi and Y. Ikeda, J. Gen. Appl. Microbiol., 12, 113 (1966).

9) H. Takahashi, H. Saito, and Y. Ikeda, Biochim. Biophys. Acta, 134, 124 (1967).

10) M. R. J. Salton, In The Bacteria, ed. by I. C. Gunsalus and R. Y. Stanier, Academic Press Inc., New York and London (1960) Vol. I, p. 97.

11) W. A. Bulen, J. E. Varner, and R. C. Burrell, Anal. Chem., 24, 187 (1952).

12) K. Sakaguchi, Agr. Biol. Chem. (Tokyo), 26, 72 (1962).

13) A. Harden, J. Chem. Soc., 79, 610 (1901).

14) H. Gest, In Phosphorus Metabolism, ed. by W. D. McElroy and B. Glass, Johns Hopkins Press, Baltimore (1952), Vol. II, p. 522.

15) M. Stephenson, Bacterial Metabolism, 3rd ed., Longmans, Green and Co., London, New York and Tronto (1950), p. 77.

16) F. Kubowitz, Biochem. Z., 274, 285 (1934).

17) F. Lipman, Adv. Enzymol. 1, 99 (1941).

18) N. M. Keridich and G. M. Tomkins, J. Biol. Chem., 241, 4955 (1966).

19) I. C. Gunsalus, In Symposium on the Mechanism of Enzyme Action, ed. by W.D. McElroY and B. Glass, Johns Hopkins Press, Baltimore (1954), p. 545.

20) A. Meister, Biochemistry of the Amino Acids, Academic Press Inc., New York and London (1965), Vol. II, p. 793.

21) P. D. Bragg and W. J. Polglase, J. Bacteriol., 88, 1006 (1964).

22) D. M. Greenberg, Metabolic Pathways, Academic Press, Inc., New York and London (1960), Vol. 1, p. 179.

23) J. W. Lightbrown, Giorn. Ital. Chemioterap., 4, 22 (1957).

24) S. Nagai, N. Yanagishima, and H. Nagai, Bacteriol. Rev., 25, 404 (1961). 
25) P. H. Sмith, E. L. Oginsky, and W. W. Umbreit, J. Bacteriol., 58, 761 (1949).

26) T. Watanabe, Keio J. Med., 3, 193 (1954).

27) L. V. Berkner and L. C. Marshall, Proc. Natl. Acad. Sci. U.S., 53, 1215 (1965).

28) A. G. Fischer, Proc. Natl. Acad. Sci. U.S., 53, 1205 (1965).

29) H. C. UReY, The Planets, Yale University Press, New Haven (1952).

30) F. Gasser and M. Sebald, Ann. Inst. Pasteur, 110, 261 (1966).

3I) F. GASSER and M. MANDEL, J. Bacteriol., 96, 580 (1969).

32) S. Orla-Jensen, The Lactic Acid Bacteria, 2nd ed. (1942) Ejnar Munksgaard, K $\phi$ benhavn. 